\title{
Efficiency Investigations of Organic/Inorganic Hybrid ZnO Nanoparticles Based Dye-Sensitized Solar Cells
}

\author{
Satbir Singh, ${ }^{1,2}$ Amarpal Singh, ${ }^{3}$ and Navneet Kaur ${ }^{4}$ \\ ${ }^{1}$ I. K. Gujral Punjab Technical University, Jalandhar, Kapurthala, Punjab 140507, India \\ ${ }^{2}$ Department of Electronics and Communication Engineering, GNDU, Regional Campus, Gurdaspur, Punjab 143521, India \\ ${ }^{3}$ Department of Electronics and Communication Engineering, Khalsa College of Engineering and Technology, \\ Amritsar, Punjab 143001, India \\ ${ }^{4}$ Center of Nanosciences and Nanotechnology, Punjab University, Chandigarh 160014, India
}

Correspondence should be addressed to Satbir Singh; satbir1_78@yahoo.co.in

Received 6 April 2016; Accepted 3 May 2016

Academic Editor: Concepción López

Copyright (C) 2016 Satbir Singh et al. This is an open access article distributed under the Creative Commons Attribution License, which permits unrestricted use, distribution, and reproduction in any medium, provided the original work is properly cited.

The present research study focuses upon the synthesis, characterization, and performances of optoelectronic properties of organicinorganic (hybrid) $\mathrm{ZnO}$ based dye sensitized solar cells. Initially, polymer dye A was synthesized using condensation reaction between 2-thiophenecarboxaldehyde and polyethylenimine and was capped to $\mathrm{ZnO}$ nanoparticles. Size and morphology of polymer dye A capped $\mathrm{ZnO}$ nanoparticles were analyzed using DLS, SEM, and XRD analysis. Further, the polymer dye was added to ruthenium metal complex $\left(\mathrm{RuCl}_{3}\right)$ to form polymer-ruthenium composite dye $\mathbf{B}$. Absorption and emission profiles of polymer dye $\mathbf{A}$ and polymer-ruthenium composite dye $\mathbf{B}$ capped $\mathrm{ZnO}$ nanoparticles were monitored using UV-Vis and fluorescence spectroscopy. Polymer dye A and polymer-ruthenium composite dye $\mathbf{B}$ capped $\mathrm{ZnO}$ nanoparticles were further processed to solar cells using wet precipitation method under room temperature. The results of investigations revealed that, after addition of ruthenium chloride $\left(\mathrm{RuCl}_{3}\right)$ metal complex dye, the light harvesting capacity of $\mathrm{ZnO}$ solar cell was enhanced compared to polymer dye A capped ZnO based solar cell. The polymer-ruthenium composite dye B capped ZnO solar cell exhibited good photovoltaic performance with excellent cell parameters, that is, exciting open circuit voltage $\left(V_{\mathrm{oc}}\right)$ of $0.70 \mathrm{~V}$, a short circuit current density $\left(J_{\mathrm{sc}}\right)$ of $11.6 \mathrm{~mA} / \mathrm{cm}^{2}$, and a fill factor (FF) of 0.65 . A maximum photovoltaic cell efficiency of $5.28 \%$ had been recorded under standard air mass (AM 1.5) simulated solar illuminations for polymer-ruthenium composite dye B based hybrid $\mathrm{ZnO}$ solar cell. The power conversion efficiency of hybrid $\mathrm{ZnO}$ based dye sensitized solar cell was enhanced by $1.78 \%$ and $3.88 \%$ compared to polymer dye $\mathbf{A}$ (concentrated) and polymer dye $\mathbf{A}$ (diluted) capped $\mathrm{ZnO}$ based dye sensitized solar cells, respectively. The hybrid organic/inorganic $\mathrm{ZnO}$ nanostructures can be implemented in a variety of optoelectronic applications in the future of clean and green technology.

\section{Introduction}

Currently, different types of photovoltaic materials, for example, organic dyes, inorganic semiconductor nanoparticles, conducting polymers, and their combinations, have been prepared for utilization in optimal optoelectronic and photovoltaic applications. The combination of organic and inorganic semiconductor material fabricates the hybrid nature of the resulting material $[1,2]$. The hybrid photo materials have different optoelectronic applications, for example, in solar cells, luminescent displays, and light sensors. The hybrid material based dye-sensitized solar cells (DSSCs) are intensively recommended as a strong, efficient, and promising alternative to the conventional single crystalline silicon based solar cells. This is due to their low cost fabrication process and good photovoltaic/photophysical properties. DSSCs based on an inorganic semiconductor material are expensive and their fabrication methods are also complex $[3,4]$. An inorganic semiconductor material possesses optimal electronic properties, photoluminescent features, good charge mobility, and high thermal stability. $\mathrm{ZnO}$ is a cheap and environment friendly inorganic material $[5,6]$. An organic material exhibits promising properties such as low synthesis cost, recyclability and easy processing, and good reliability 
[7-10]. An organic/inorganic hybrid DSSC combines the advantageous features of conjugated or conducting polymer and wide band gap inorganic semiconductor material's nanoparticles. The combined absorption band of hybrid material has high photons (sunlight) harvesting capacity. The conducting polymers have been combined with variety of inorganic semiconductors, for example, $\mathrm{ZnO}, \mathrm{TiO}_{2}$, and CdSe. In the class of resulting hybrid material, there is generation of induced charge carrier's separation at the interface of organic-inorganic material. This photo charge carrier separation is responsible for the injection of electrons from conducting polymer into inorganic semiconductor material. The polymer consists of hole vacancies and the combination of holes and electrons takes place at donor-acceptor (D-A) interface. An exciton is produced from the bound relation of electron-hole pair. The excitons absorbed in the inorganic semiconductor material produce the photogeneration of charge carriers. The light absorption profile and wide band gap nature of inorganic semiconductor material can be modified by quantum confinement effect [11-16]. By taking the advantages of this way, researchers can effectively increase the harvesting capacity of dye molecules and power conversion efficiency of dye-sensitized solar cell. For the present research work, the fabrication of DSSC is based upon an organic polymer dye, inorganic oxide semiconductor material $(\mathrm{ZnO})$, and ruthenium metal complex material. During the fabrication process of DSSC, the semiconductor $\mathrm{ZnO}$ (wide band gap) nanoparticles were capped by a layer of polymer dye molecules on a transparent conductive film in the form of photosensitized anode. The advantages of polymer decorated $\mathrm{ZnO}$ nanoparticles include the nonaggregation phenomenon which modifies the surface of $\mathrm{ZnO}$ nanoparticles by using the process of surface passivation [17-20]. It also provides the large nanocrystalline surface area for the absorption of light photons and significant enhancement of the light harvesting capacity of photoelectrode. Hence, the overall photovoltaic efficiency of the solar cell increases [14]. In the middle section of DSSC, a liquid electrolyte was used that contained a redox couple. It connected two conductors (anode and cathode) of the cell electrically $[21,22]$. At the final fabrication stage of dye-sensitized solar cell, a counter electrode was prepared and fixed upon the other side of cell. The conductive substrate coated material such as $\mathrm{Pt}$, carbon, or graphite can be used as a counter electrode or cathode for the solar cell. The dye material (polymer dye or ruthenium metal complex dye) absorbs the maximum sunlight and produces photons or excitons that are split across the surface area of polymer decorated $\mathrm{ZnO}$ nanoparticles. This phenomenon leads to the generation of photoelectrons which are injected into conduction band of semiconductor $\mathrm{ZnO}$ [23-27]. Hence, at the counter electrode section, the transported electrons from polymer decorated $\mathrm{ZnO}$ and migrated holes from electrolyte solution recombine and generate photovoltage in the $\mathrm{mV}$ (millivolt) ranges. Till date, the highest power conversion efficiency reported for $\mathrm{ZnO}$ based DSSC is up to 7.5\% [17]. In the literature reviewed, many research papers have been deeply studied and analyzed in reference to polymer and ruthenium dyes based $\mathrm{ZnO}$ solar cells. Singh et al. [6] demonstrated the effect of thiol derivatized $\mathrm{Ru}$-based dye on
ZnO based DSSC. Zhang et al. [10] synthesized and studied the $\mathrm{ZnO}$ aggregates in the form of nanosized crystallites on the enhanced light harvesting performance of DSSC. Liu [2] reviewed the concept of organic/inorganic hybrid nanocomposites for photovoltaic cells. In case of hybrid solar cell materials, more improvements in efficiency can be expected. Kumar et al. [28] reported the efficiencies up to $1.56 \%$ and $1.84 \%$ for boron and aluminum doped $\mathrm{ZnO}$ based DSSCs, respectively. There are many fabrication techniques for $\mathrm{ZnO}$ based hybrid DSSCs including wet precipitation, thin film deposition method, spray coating, spin coating, solgel method, screen printing, chemical vapor deposition, and hydrothermal technique $[10,12]$. The present research work focused on the optoelectronic and photovoltaic performances of hybrid $\mathrm{ZnO}$ material for DSSC. We have used wet precipitation method for the preparation of polymer decorated $\mathrm{ZnO}$ nanoparticles. These polymer decorated $\mathrm{ZnO}$ nanoparticles are used as an active layer on the indium tin oxide (ITO) glass substrate acting as an anode. The DSSCs performances were recorded with the addition of organic polymer dye to $\mathrm{ZnO}$ nanoparticles and polymer-ruthenium metal complex dye to $\mathrm{ZnO}$ comparatively.

(1) Polymer Dye Capped ZnO DSSC. The dye-sensitized solar cell was invented by Professor Graetzel using ruthenium metal complexes for improving and enhancing the photonto-electronic current conversion efficiency compared to solid state silicon based solar cells [29]. Till 2013, record 24.7\% solar cell efficiency was achieved by HIT silicon solar cell [30]. The hybrid $\mathrm{ZnO}$ based DSSCs do not require complex and sophisticated fabrication method as in the case of silicon solar cells. In the modern era of engineering and nanotechnology, very transparent, flexible, and colorful DSSCs can be fabricated for different optoelectronic applications. Figure 1 shows the basic schematic of polymer dye capped $\mathrm{ZnO}$ based DSSC. As shown in the schematic, polymer dye molecules play a vital role of (photons) absorbers from direct sunlight or simulated light conditions (photon emission source). A high absorption spectrum of the dye molecules produces strong stream of photocurrent inside the $\mathrm{ZnO}$ based DSSC. The overall quantum efficiency of $\mathrm{ZnO}$ based DSSC improves due to optimal injection of electronic charge from ground state (S-valance band) to excited state ( $\mathrm{S}^{*}$-conduction band) from smooth surface grafting of oxide nanoparticles. The photoanode section of DSSC absorbs dye molecules and performs the conduction of photoelectrons. $\mathrm{ZnO}$ is a wide band gap n-type semiconductor material broadly used as a photoanode in the solar cells. Polymer decorated $\mathrm{ZnO}$ nanoparticles show remarkable advantages, when utilized as a layer of photoanode in the solar cells. The liquid electrolyte is used in the $\mathrm{ZnO}$ based DSSC due to its good surface wetting properties. It prevents the dye molecules from dryness. The liquid electrolyte contains an iodide/tri-iodide $\left(\mathrm{I}^{-} / \mathrm{I}_{3}{ }^{-}\right)$ redox pair that transfer electronic charges throughout the electrolyte. The chemisorption process, which is initiated by dye molecules and light radiations, produces the injection of electrons from HOMO to LUMO states of energy. The redox pair process $\left(\mathrm{I}^{-} / \mathrm{I}_{3}^{-}\right)$reduces the dye ions at counter electrode (cathode) section of DSSC. So, the energy difference between 


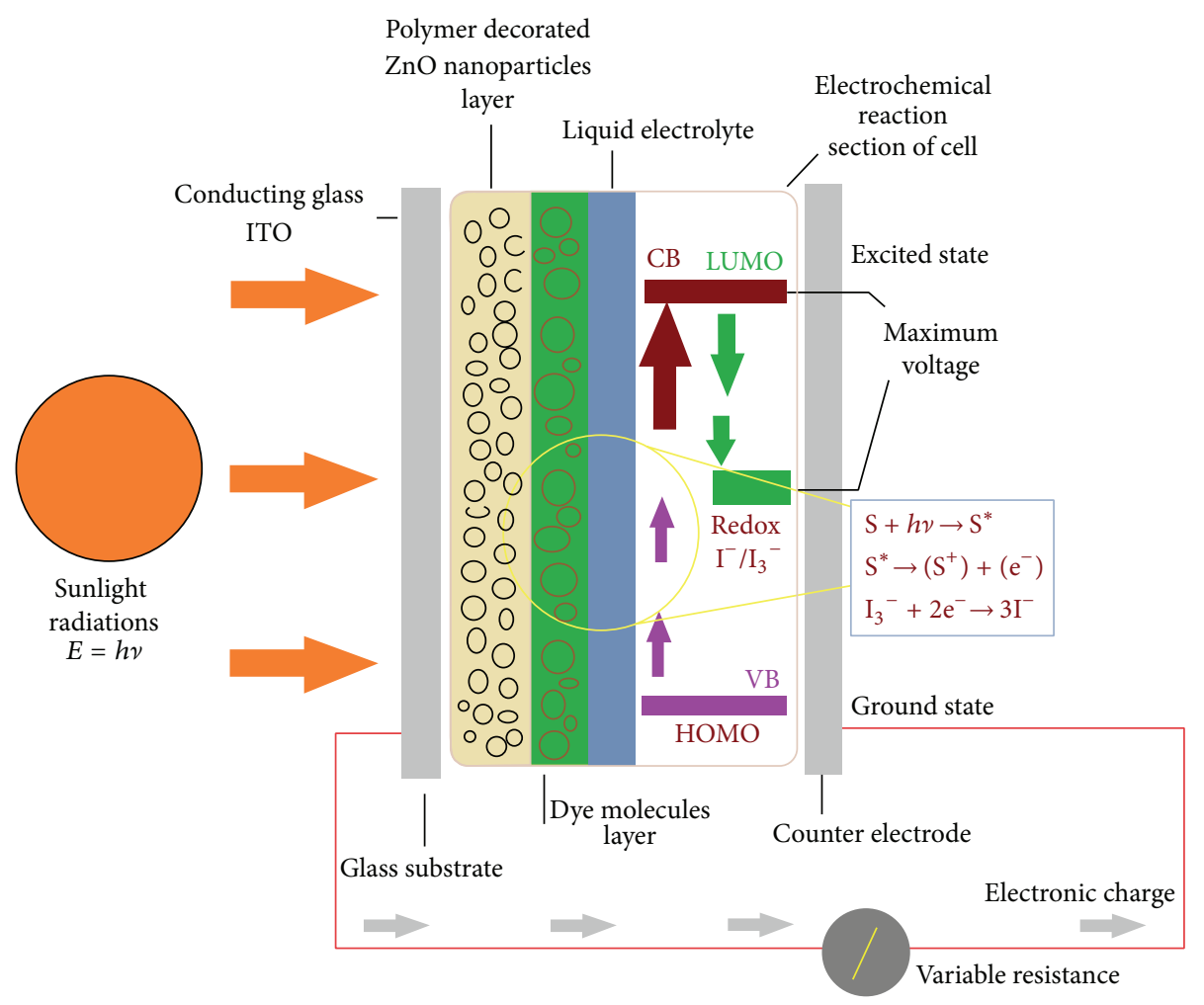

FIgURE 1: Schematic of polymer dye capped ZnO based DSSC.

the Fermi energy state and redox potential state generates the maximum voltage in $\mathrm{mV}$ ranges.

\section{Experimental Technique}

This section deeply focuses on the synthesis procedure and structural characteristics of polymer dye $\mathbf{A}$ and polymerruthenium composite dye $\mathbf{B}$ capped $\mathrm{ZnO}$ nanoparticles.

2.1. Materials and Measuring Instruments. For synthesis process, all the chemical materials were purchased from a commercial dealer and were used without further purification. ${ }^{1} \mathrm{H}$ NMR (nuclear magnetic resonance) and ${ }^{13} \mathrm{C}$ NMR (nuclear magnetic resonance) spectra were recorded on Avance-II (Bruker) instrument, which was operated at $400 \mathrm{MHz}$ for ${ }^{1} \mathrm{H}$ NMR. The $\mathrm{CHN}$ (carbon, hydrogen, and nitrogen) analysis was performed on PerkinElmer $2400 \mathrm{CHN}$ Elemental Analyzer. For cation recognition studies, the UVVis absorption spectra were taken using dilute solutions in quartz cells ( $1 \mathrm{~cm}$ path length). The fluorescence profile of sensor solutions was recorded on PerkinElmer L55 Fluorescence spectrophotometer using $1 \mathrm{~cm}$ path length of quartz cells. Scanning electron microscopic (SEM) studies were conducted on samples obtained after drying the aqueous solutions of materials $(10 \mu \mathrm{M})$ and SEM images were taken by JEOL JSM-6610LV scanning electron microscope which was operated at $15 \mathrm{KeV}$. The particle size of organic nanoparticles (ONPs) was determined by Dynamic Light Scattering (DLS) using external probe feature of Microtrac Ultra Nanotrac
Particle Size Analyzer instrument. For analyzing, $10 \mu \mathrm{M}$ concentration of solution was used and presented results are the average of 20 scans $\times 240$ pixels recorded with Camtasia recorder at 12 frames/s. The crystal structure of the $\mathrm{ZnO}$ powders was analyzed by X-ray diffraction (XRD) with a PANalytical X'PERT PRO diffractometer operated at $45 \mathrm{KV}$ and $40 \mathrm{~mA}$ using $\mathrm{Ni}$-filtered $\mathrm{Cu} \mathrm{K} \alpha$ radiations with a scan speed of $10^{\circ} / \mathrm{min}$ for $2 \theta$ in a range from 10 to 75 . The average crystalline size of polymer dye capped $\mathrm{ZnO}$ nanoparticles was calculated with Debye-Scherrer's equation using XRD analysis data [31]. The DSSC performance was evaluated by measurement of current and voltage curves (with OMEGA DMM 101 digital multimeter) under simulated solar light source (Xenon Light Projector) with air mass (AM) 1.5 solar irradiation.

2.2. Synthesis of Polymer Dye A. Polymer dye A was synthesized by reaction of 2-thiophenecarboxaldehyde $(1,1 \mathrm{mmol})$ and polyamine $(2,2.5 \mathrm{mmol})$ in dry methanol as shown in Figure 3. After the completion of reaction (TLC), solvent was evaporated under reduced pressure. A pale yellow product was separated out and product was washed by methanol and polymer dye was characterized by ${ }^{1} \mathrm{H}$ NMR and mass and IR and CHN spectroscopy. A light yellow solid was obtained in $87 \%$ yield $(195 \mathrm{mg})$. mp (melting point) $>190^{\circ} \mathrm{C}$; IR (KBr): $\nu_{\max } 1660,1532,1245,1222 \mathrm{~cm}^{-1} ;{ }^{1} \mathrm{H} \mathrm{NMR}(400 \mathrm{MHz}$, $\left.\mathrm{CDCl}_{3}\right): \delta=8.10(\mathrm{~s}, 4 \mathrm{H}, \mathrm{CH}=\mathrm{N}), 7.75-7.72(\mathrm{~m}, 3 \mathrm{H}, \mathrm{ArHs})$, 7.66 (dd, $1 \mathrm{H}, \mathrm{ArH}), 7.44-7.36$ (m, 4H, ArHs), 7.22-7.13 (m, 4H, ArHs), $3.76\left(\mathrm{t}, 2 \mathrm{H}, \mathrm{CH}_{2}\right), 3.68\left(\mathrm{t}, 4 \mathrm{H}, \mathrm{CH}_{2}\right), 3.45-3.90(\mathrm{~m}, 4 \mathrm{H}$, 
$\left.\mathrm{CH}_{2}\right), 3.18(\mathrm{~s}, 1 \mathrm{H}, \mathrm{NH}), 3.07-2.91\left(\mathrm{~m}, 4 \mathrm{H}, \mathrm{CH}_{2}\right), 2.85-2.69(\mathrm{~m}$, $\left.6 \mathrm{H}, \mathrm{CH}_{2}\right), 2.61-2.50\left(\mathrm{~m}, 6 \mathrm{H}, \mathrm{CH}_{2}\right), 2.54-2.50\left(\mathrm{~m}, 4 \mathrm{H}, \mathrm{CH}_{2}\right)$, 2.45-2.42 (m, 4H, $\left.\mathrm{CH}_{2}\right), 2.38-2.33\left(\mathrm{~m}, 4 \mathrm{H}, 2 \times \mathrm{CH}_{2}\right), 1.91-$ $1.85\left(\mathrm{~m}, 2 \mathrm{H}, \mathrm{CH}_{2}\right), 1.65$ (s, 1H, NH), 1.64 (s, 1H, NH), 1.631.55 (m, 1H, CH), 1.49-1.45 (m, 2H, $\mathrm{CH}_{2}$ ); MS (ESI): $m / z 859$ $\left(\mathrm{M}+\mathrm{Na}^{+}\right)$; Anal. calcd. For $\mathrm{C}_{42} \mathrm{H}_{62} \mathrm{~N}_{10} \mathrm{~S}_{4}$ : C, 60.25; H, 7.70; N, 16.73 Found: C, $60.16 ; \mathrm{H}, 7.59 ; \mathrm{N}, 16.66 \%$.

2.3. Preparation of Polymer Dye A Capped ZnO Nanoparticles. Initially, the solution of $\mathrm{ZnO}$ was synthesized by mixing the alcoholic solution of $\mathrm{Zn}\left(\mathrm{NO}_{3}\right)_{2} \cdot 6 \mathrm{H}_{2} \mathrm{O}(595 \mathrm{mg}, 2.0 \mathrm{mmol})$ with alcoholic solution of $\mathrm{NaOH}(120 \mathrm{mg}, 3.0 \mathrm{mmol})$. A white product was separated out and the product was washed by ethanol. The product was dried at $150^{\circ} \mathrm{C}$. Polymer dye $\mathbf{A}$ was taken along with $\mathrm{ZnO}(100 \mathrm{mg})$ in dry $\mathrm{CHCl}_{3}$ and the solution was refluxed for 6 hours. The progress of dye coating was monitored by IR and UV-Vis absorption spectroscopy by taking a small sample from the reaction mixture at different intervals. Upon completion of reaction, light yellow colored solid polymer dye A capped $\mathrm{ZnO}$ nanoparticles were separated out. Polymer dye A capped $\mathrm{ZnO}$ nanoparticles were further washed with excess of methanol and dried under vacuum. Polymer dye A capped $\mathrm{ZnO}$ nanoparticles were characterized using DLS, SEM, and solid state XRD [28].

2.4. Formation of Polymer-Ruthenium Metal Complex as Composite Dye B. The polymer compounds $(604 \mathrm{mg}, 3 \mathrm{mmol}$ ) were taken along with $\mathrm{RuCl}_{3}$ trihydrate complex (100 mg) in dry $\mathrm{MeOH}$ and the solution was refluxed for $10 \mathrm{~h}$. The progress of the reaction was monitored by IR and UV-Vis absorption spectroscopy by taking a small sample from the reaction mixture. Upon completion of reaction, solution was concentrated, cooled, and stirred with petroleum ether. The resultant solid was washed by dichloromethane and dried in vacuum over anhydrous calcium chloride. Polymer Schiff base showed strong absorption band in the region of 1630$1660 \mathrm{~cm}^{-1}$. However, upon complexion with the metal it shifted to lower frequency indicating formation of the metal complex with $\mathrm{CH}=\mathrm{N}$. Hence, polymer-ruthenium composite dye $\mathbf{B}$ was prepared and was used as a good light harvester in $\mathrm{ZnO}$ solar cell.

2.5. Fabrication of $\mathrm{ZnO}$ Based DSSC. For the fabrication of $\mathrm{ZnO}$ based DSSCs, we have prepared two different dyes: polymer dye A and polymer-ruthenium metal complex dye B, respectively. Both of the dyes were separately pasted on a cleaned and dried ITO conductive glass sheet, which acted as a photoanode. Further, polymer dye A was prepared into a diluted form and processed for fabrication of $\mathrm{ZnO}$ based DSSC. The polymer dye capped thin sheet of $\mathrm{ZnO}$ nanoparticles was air-dried at room temperature $\left(25^{\circ} \mathrm{C}\right)$. The surface area of this sheet was selected as $1.0 \mathrm{~cm}^{2}$. The conductive side of carbon dust (obtained from candle flame) coated counter electrode was placed on top of the anode sheet. A liquid electrolyte (iodide/tri-iodide) based solution was placed at the top of the conductive edge of cell. This liquid electrolyte was put into the space between the two conductive electrodes with capillary action. Thereafter, two good black binder clips were used to hold the electrodes together. The effective cell surface area was $1.0 \mathrm{~cm}^{2}$ as shown in Figure 2. The polymer dye capped $\mathrm{ZnO}$ nanoparticles layer was fixed on ITO conductive glass (as shown in Figures 2(A) and 2(B)). A counter electrode in the form of carbon dust flamed with a candle on another conductive ITO glass has been shown in Figure 2(C). Finally, the circuit assembly of $\mathrm{ZnO}$ based DSSC was ready for measuring different parameters, that is, short circuit current density $\left(J_{\mathrm{sc}}\right)$, open circuit voltage $\left(V_{\mathrm{oc}}\right)$, fill factor, and incident photoelectric conversion efficiency represented in Figure 2(D).

For measuring photovoltaic characteristics, that is, current density and photovoltage curve, an ultrafine digital multimeter was connected to the electrodes of $\mathrm{ZnO}$ based DSSC with variable resistances. The light intensity of simulated source used was $100 \mathrm{~mW} / \mathrm{cm}^{2}$. This is equivalent to one sun or AM (air mass) 1.5 of photon power that is delivered to the surface area of $\mathrm{ZnO}$ based DSSC. The photoelectric conversion efficiency $(\eta)$ of DSSC depends upon four main parameters. These four parameters of DSSC are related as

$$
\text { Efficiency }(\eta)=\frac{\text { Current Density }\left(J_{\mathrm{sc}}\right) \times \text { Open Circuit Voltage }\left(V_{\mathrm{oc}}\right) \times \text { Fill Factor }}{P_{\text {in }}}
$$

Here, the fill factor (ff) is the ratio of maximum power to the measured short circuit current density $\left(J_{\mathrm{sc}}\right)$ and open circuit voltage $\left(V_{\text {oc }}\right)$ values. So, fill factor measurement is given as

$$
\mathrm{ff}=\frac{\text { Maximum Power }\left(P_{\max }\right) \times J_{\mathrm{sc}}}{V_{\mathrm{oc}}} .
$$

For measuring maximum power $\left(P_{\max }\right)$, first open circuit voltage is measured when the current value in the DSSC is almost zero. Similarly, short circuit current density is measured after inserting variable resistance $(R)$ in shunt with the
$\mathrm{ZnO}$ based DSSC circuit. Hence, maximum power $\left(P_{\max }\right)$ delivered with the DSSC is

$$
P_{\max }=V_{\max } \times I_{\max } .
$$

The overall performance of $\mathrm{ZnO}$ based DSSC is basically dependent on the characteristics of the factors expressed above. For obtaining better results from polymer dyesensitized $\mathrm{ZnO}$ solar cells, a lot of research works were carried out throughout the world to examine the various cell components/materials preparation methods, nature of hybrid material used, effect of processing factors on these materials, stability of dye, and performance of liquid electrolyte as well as conductive electrodes. 


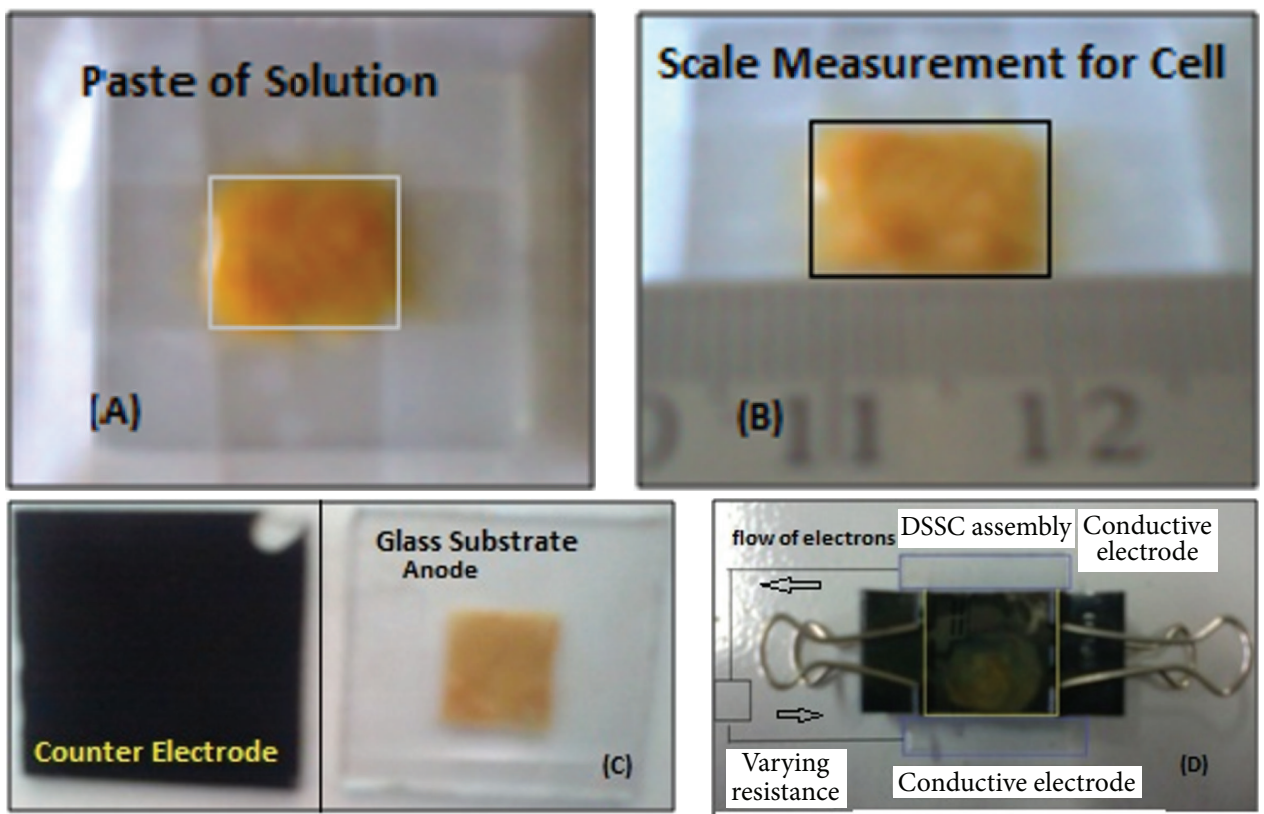

FIgure 2: Assembly sections of polymer decorated $\mathrm{ZnO}$ based DSSC. ((A) and (B)) Polymer dye capped ZnO nanoparticles in the form of a paste on ITO conductive sheet acting as a photoanode having a surface area $1 \mathrm{~cm} \times 1 \mathrm{~cm},(\mathrm{C})$ counter electrode acting as a cathode for DSSC made from candle dust, and (D) circuit diagram of DSSC for measuring current density and open circuit voltage for DSSC.

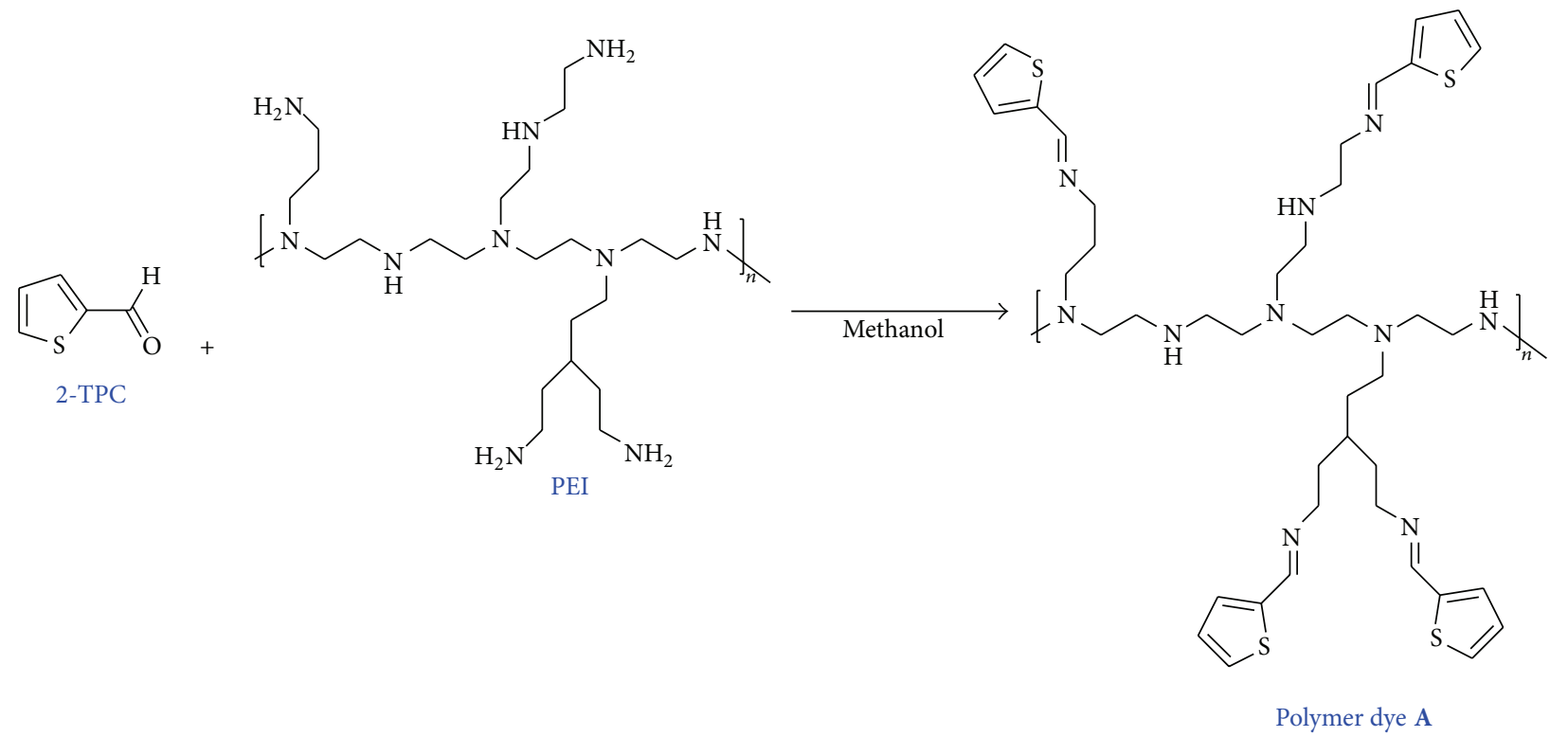

Figure 3: Chemical structure of polymer dye A.

\section{Results and Discussion}

3.1. Morphology of the Polymer Dye Capped ZnO Nanoparticles. The surface morphology and size distribution of polymer dye capped $\mathrm{ZnO}$ nanoparticles were investigated by SEM (JEOL JSM-6610) operated at $15 \mathrm{KV}$. SEM image of polymer dye capped on $\mathrm{ZnO}$ nanoparticles appears to be homogenously arranged (as shown in Figure 4(a)). Energy dispersive spectroscopy (EDS) elemental mapping images of polymer decorated $\mathrm{ZnO}$ nanoparticles confirmed the presence of finely dispersed zinc, carbon, and oxygen in nanoparticle (as shown in Figure 4(b)). In the EDS spectra of polymer decorated $\mathrm{ZnO}$ nanoparticles, all the characteristics peaks were well matched with their unique elements of $\mathrm{Zn}$ and $\mathrm{O}$ [32]. The carbon peak occurred due to the supporting substrate (organic material) used for SEM sampling. The atomic percentages (atomic \%) of $\mathrm{Zn}, \mathrm{O}$, and $\mathrm{C}$ in the composition are $40.23 \%, 34.59 \%$, and $25.18 \%$, respectively.

DLS images analysis shown in Figure 5 depicts that the size of polymer dye capped $\mathrm{ZnO}$ nanoparticles was found to 
TABLE 1: Photovoltaic performances of hybrid ZnO based dye-sensitized solar cells (DSSCs) under simulated solar illuminations (AM 1.5).

\begin{tabular}{|c|c|c|c|c|c|c|}
\hline Sample name & Name of DSSC & $\begin{array}{l}\text { Open circuit } \\
\text { voltage } V_{\text {oc }} \\
\text { (volts) }\end{array}$ & $\begin{array}{l}\text { Short circuit } \\
\text { current density } \\
J_{\mathrm{sc}}\left(\mathrm{mA} / \mathrm{cm}^{2}\right)\end{array}$ & $\begin{array}{l}\text { Fill factor } \\
\quad(\mathrm{FF})\end{array}$ & $\begin{array}{l}\text { Thickness of } \\
\text { photoanode } \\
\text { layer }(\mu \mathrm{m})\end{array}$ & $\begin{array}{l}\text { Efficiency of } \\
\text { DSSC }(\eta \%)\end{array}$ \\
\hline A & $\begin{array}{l}\text { Polymer dye } \mathbf{A} \text { (dil.) + } \mathrm{ZnO} \\
\text { DSSC }\end{array}$ & 0.55 & 4.4 & $58 \%$ & 10.57 & 1.40 \\
\hline B & $\begin{array}{l}\text { Polymer dye } \mathbf{A} \text { (conc.) }+\mathrm{ZnO} \\
\text { DSSC }\end{array}$ & 0.67 & 8.7 & $60 \%$ & 16.11 & 3.50 \\
\hline C & $\begin{array}{l}\text { Polymer-ruthenium } \\
\text { composite dye } \mathbf{B}+\mathrm{ZnO} \text { DSSC }\end{array}$ & 0.83 & 12.6 & $65 \%$ & 25.40 & 5.28 \\
\hline
\end{tabular}

be $7.45 \mathrm{~nm}$, while, comparing with respect to JCPDS card (361451), the particle size was found to be $18 \mathrm{~nm}$.

3.2. Structural Investigations: X-Ray Diffraction (XRD). For structural investigations of $\mathrm{ZnO}$ nanoparticles, XRD spectrum was collected using PANalytical X'PERT PRO diffractometer. It was operated at $45 \mathrm{KV}$ and $40 \mathrm{~mA}$ using $\mathrm{Ni}$ filtered $\mathrm{Cu} \mathrm{K} \alpha$ radiations with a scan speed of $10^{\circ} / \mathrm{min}$ for $2 \theta$ in a range from $10^{\circ}$ to $75^{\circ}$. Crystallite size of the synthesized polymer dye capped $\mathrm{ZnO}$ nanoparticles was characterized and analyzed by using XRD technique. For comparison purpose, we had synthesized non-polymer decorated $\mathrm{ZnO}$ nanoparticles using the appropriate precursors. Debye-Scherrer's equation [31], given by $D=0.9 \lambda /(\beta \cos \theta)$, was used to compute the crystallite size of both capped and uncapped $\mathrm{ZnO}$ nanoparticles. In the above equation, $D$ is crystallite size, $\beta$ is the full width at half maxima (FWHM), and $\lambda$ is giving the value of the wavelength of the copper $(\mathrm{Cu})$ radiation. The particle size of uncapped $\mathrm{ZnO}$ nanoparticle was found to be $32 \mathrm{~nm}$, which corresponds to different peaks in different planes (100), (101), (002), (102), (110), (103), and (112) as shown in Figure 6(b). In case of capped $\mathrm{ZnO}$ nanoparticles, XRD spectra (in Figure 6(a)) show the presence of broad peaks at $32.01^{\circ}, 35.52^{\circ}, 38.24^{\circ}, 48.48^{\circ}, 62.75^{\circ}, 63.40^{\circ}$, and $65.33^{\circ}$. The broadening of large XRD peaks confirms that size of polymer capped $\mathrm{ZnO}$ nanoparticles was smaller compared to that of uncapped $\mathrm{ZnO}$ nanoparticles. While comparing with respect to JCPDS card (36-1451), particle size was found to be in range of $18 \mathrm{~nm}$. Figure 6(b) illustrates that, with surface modifications, the peaks of the XRD pattern of polymer dye capped $\mathrm{ZnO}$ nanoparticles seemed to be broadened and main peaks were still in accordance with the wurtzite structure of $\mathrm{ZnO}$, which indicates that the surface modified (polymer dye capped) $\mathrm{ZnO}$ nanoparticles do not affect the crystalline structure of $\mathrm{ZnO}$. The aggregation of $\mathrm{ZnO}$ nanoparticles affects the practical applicability such as in case of dye-sensitized solar cells and display devices. Surface modification of $\mathrm{ZnO}$ nanoparticles is used to eliminate the aggregated surfactants. So, we had used 2-TPC as an effective functional group or legend to decorate polymer dye on $\mathrm{ZnO}$ nanoparticles.

3.3. Fluorescence Spectra of Dyes Capped ZnO Nanoparticles. The fluorescence spectra have been recorded by exciting the samples at the wavelength of $325 \mathrm{~nm}$. The fluorescence spectra of three different samples A, B, and C (polymer dye A (dil.) capped $\mathrm{ZnO}$ nanoparticles, polymer dye A (conc.) capped $\mathrm{ZnO}$ nanoparticles, and polymer-ruthenium composite dye $\mathbf{B}$ capped $\mathrm{ZnO}$ nanoparticles) showed the near to strong ultraviolet region (narrow high peaks) accompanied by the medium and small broadened peaks at visible region. Figure 7 showed a maximum excitation peak at $353 \mathrm{~nm}$ for polymer dye A capped $\mathrm{ZnO}$ nanoparticles. For polymerruthenium metal complex composite dye, the fluorescence spectra showed an excitation peak at $352 \mathrm{~nm}$. Similarly, the visible region of the photoluminescence spectra showed different peaks at $446 \mathrm{~nm}, 451 \mathrm{~nm}$, and $460 \mathrm{~nm}$ for samples $\mathrm{A}, \mathrm{B}$, and $\mathrm{C}$, respectively. An interesting observation in the fluorescence spectra was the IR emission at $697 \mathrm{~nm}$ and $701 \mathrm{~nm}$ for samples A and C. The blue-green emission for broadened spectrum peaks formed from surface defects was present in the $\mathrm{ZnO}$ material (as shown in Figure 7).

3.4. UV-Visible Spectra of Dyes Capped ZnO Nanoparticles. The UV-visible portion depicted the significance of optoelectronic features of $\mathrm{ZnO}$ nanoparticles for different three samples A (diluted polymer dye A), B (concentrated polymer dye $\mathbf{A}$ ), and $\mathrm{C}$ (polymer-ruthenium metal complex based composite dye B). The measurements of UV-visible absorption spectra were recorded at room temperature. Figure 8 showed the significant absorbance peaks observed at $314 \mathrm{~nm}$, $315 \mathrm{~nm}$, and $317 \mathrm{~nm}$ for samples A, B, and C. The absorption peak for diluted polymer dye A capped $\mathrm{ZnO}$ nanoparticles was observed at $314 \mathrm{~nm}$; the absorbance peak showed less absorption compared to that of concentrated polymer dye $\mathbf{A}$ based $\mathrm{ZnO}$ nanoparticles $(315 \mathrm{~nm})$ and polymer-ruthenium based composite dye B $(317 \mathrm{~nm})$. The highest absorption peak appeared for polymer-ruthenium based composite dye molecules, that is, at $317 \mathrm{~nm}$. Two more absorption bands had been observed at $395 \mathrm{~nm}$ and $451 \mathrm{~nm}$ for sample A. Similarly, for sample C, absorption bands had been observed at $394 \mathrm{~nm}$ and at $445 \mathrm{~nm}$. For sample B, a small absorption band had been observed at $420 \mathrm{~nm}$. Hence, sample $\mathrm{C}$ showed high light harvesting capability due to the transfer of composite dye molecules from donor to acceptor region after capping of 2-TPC and PEI to $\mathrm{ZnO}$ nanoparticles. The corresponding shifts in the absorption spectra resulted due to the quantum confinement effect that occurred in $\mathrm{ZnO}$ nanoparticles [33, 34].

3.5. Photovoltaic Performances of Hybrid ZnO Based DSSCs. The current density and voltage characteristics of polymer 


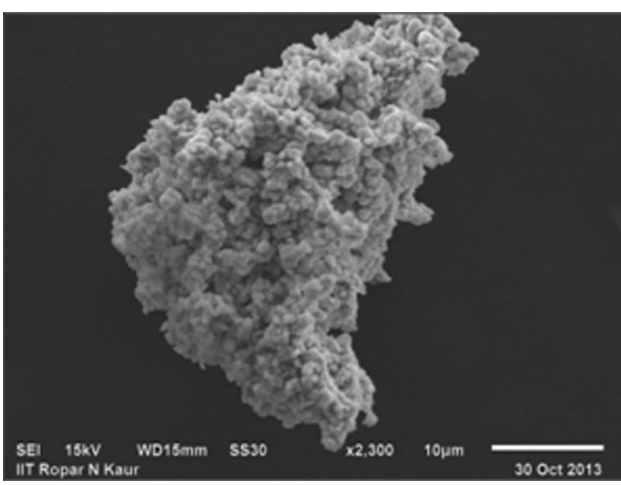

(a)

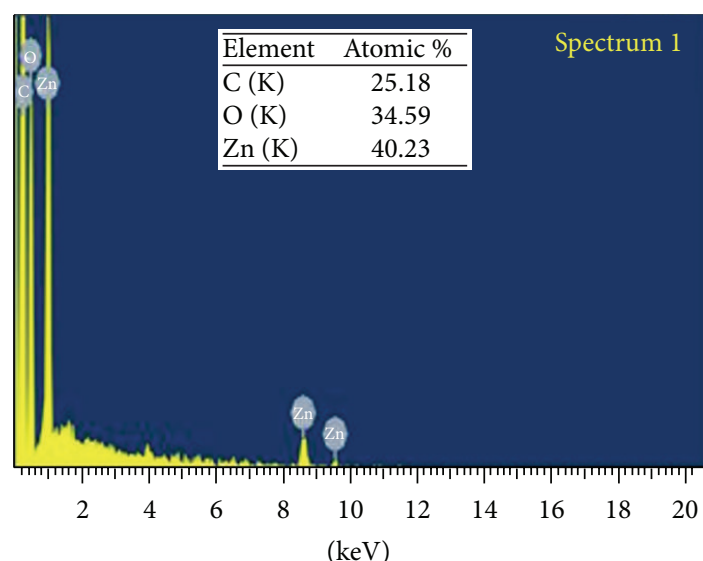

Full-scale 243 cts cursor: 0.000

(b)

FIGURE 4: SEM image of ZnO nanoparticles: (a) high magnification image of polymer decorated ZnO nanoparticles and (b) EDS spectra of polymer decorated $\mathrm{ZnO}$ nanoparticles.

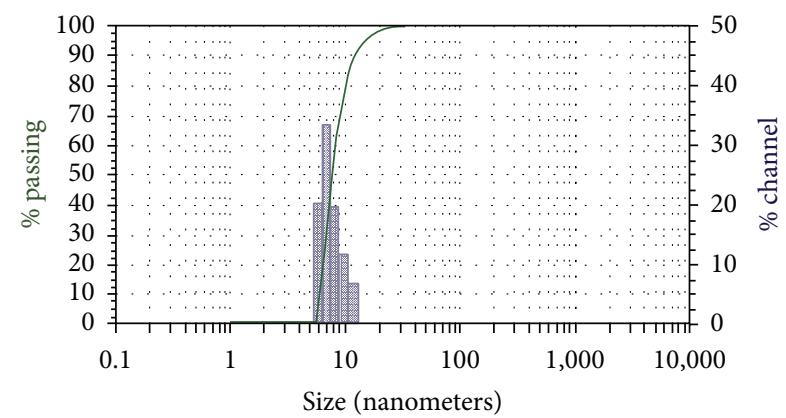

FIgURE 5: DLS spectra of polymer dye capped $\mathrm{ZnO}$ nanoparticles.

decorated hybrid ZnO DSSCs had been recorded for different samples $A, B$, and $C$ by varied external resistances under simulated sunlight illuminations or AM 1.5 solar conditions (shown in Figure 9). The various dye-sensitized solar cell parameters, for example, current density, open circuit voltage, fill factor (FF), thickness of photoanode layer, and solar energy-to-electricity conversion efficiency $(\eta)$ of polymer decorated hybrid ZnO DSSCs, were calculated and presented in Table 1. The photovoltaic performances of $\mathrm{ZnO}$ based DSSCs were calculated under simulated photo illumination $\left(100 \mathrm{~mW} / \mathrm{cm}^{2}\right)$. The maximum power conversion efficiency had been recorded and calculated for polymer-ruthenium metal complex based composite dye B sensitized solar cell. The photovoltaic parameters for the polymer-ruthenium based composite dye B based ZnO DSSC (sample C) showed an open circuit voltage $\left(V_{\text {oc }}\right)$ of 0.83 volts, a short circuit current density $\left(J_{\mathrm{sc}}\right)$ of $12.6 \mathrm{~mA} / \mathrm{cm}^{2}$, a fill factor of $65 \%$, and an overall photon-to-electric power conversion efficiency $(\eta)$ of $5.28 \%$. In order to compare this photovoltaic performance with other DSSCs, $(\eta)$ was measured at $3.50 \%$, with $V_{\text {oc }}$ of 0.67 volts, short circuit current density of $8.7 \mathrm{~mA} / \mathrm{cm}^{2}$, and fill factor of $60 \%$ in case of concentrated polymer dye $\mathrm{A}$ based $\mathrm{ZnO}$
DSSC (sample B). The least photovoltaic performance was recorded in case of diluted polymer dye A only. In this case, the power conversion efficiency $(\eta)$ measured was $1.40 \%$, with an open circuit voltage $\left(V_{\mathrm{oc}}\right)$ of 0.55 volts, short circuit current density of $4.4 \mathrm{~mA} / \mathrm{cm}^{2}$, and fill factor of $58 \%$. The thickness of the photoanodes (in $\mu \mathrm{m}$ ) for the current $\mathrm{ZnO}$ based DSSCs showed a significant increase in the photonto-electric power conversion efficiency. The thickness of the photoanode layers was calculated to be $10.57 \mu \mathrm{m}, 16.11 \mu \mathrm{m}$, and $25.40 \mu \mathrm{m}$ for samples A, B, and C, respectively, by using 3 micromolars per centimeter square and the calculations were performed as per the method given in the literature [35-37]. The coating of another material over the parent $\mathrm{ZnO}$ leads to increase in the thickness of the coating. This is due to the increase in the composite molecular weight and eventually increases the thickness of the photoanode layer. However, the increase in the size of composite leads to decrease in the surface over mass ratio and vice versa. As the thickness of polymer capped $\mathrm{ZnO}$ photoanode layer increases for an effective surface area $\left(1.0 \mathrm{~cm}^{2}\right)$ of the cell, the electrons recombine easily with the redox coupler within the cell and hence the power conversion efficiency of $\mathrm{ZnO}$ based DSSC increases (shown in Figure 10). The thickness of each photoanode (for samples A, B, and C) has an exclusive dye adsorption time period at which the maximum photon-to-electric power conversion efficiency occurs. The dye adsorption times recorded for samples $\mathrm{A}, \mathrm{B}$, and $\mathrm{C}$ were 1 hour, 1.5 hours, and 2.0 hours, respectively. A comparison of thickness of photoanode and power conversion efficiency $(\eta)$ of $\mathrm{ZnO}$ based DSSCs for different samples A, B, and C is shown in Figure 10. A maximum power conversion efficiency of $5.27 \%$ has been recorded for a photoanode thickness of $25.40 \mu \mathrm{m}$ for sample C based DSSC.

The highest recorded efficiency for polymer-ruthenium composite dye B capped ZnO DSSC was enhanced by $1.78 \%$ and $3.87 \%$ compared to that of polymer dye $\mathbf{A}$ (conc.) capped and polymer dye $\mathbf{A}$ (dil.) capped ZnO DSSCs. This significant 


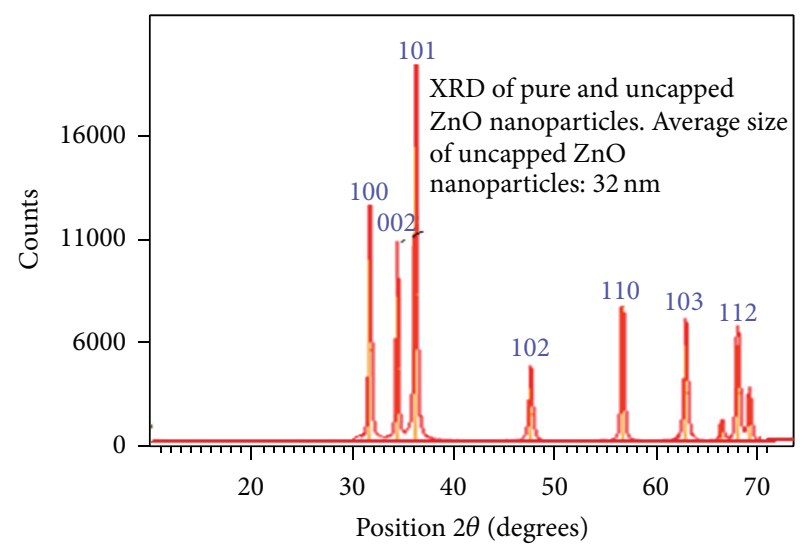

(a)

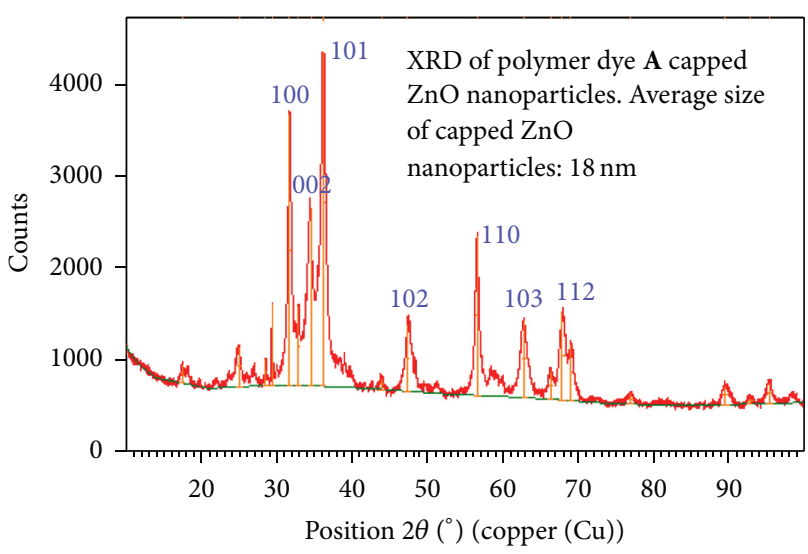

(b)

FIgURE 6: X-ray diffractogram of (a) uncapped $\mathrm{ZnO}$ nanoparticles and (b) polymer dye A capped zinc oxide (ZnO) nanoparticles.

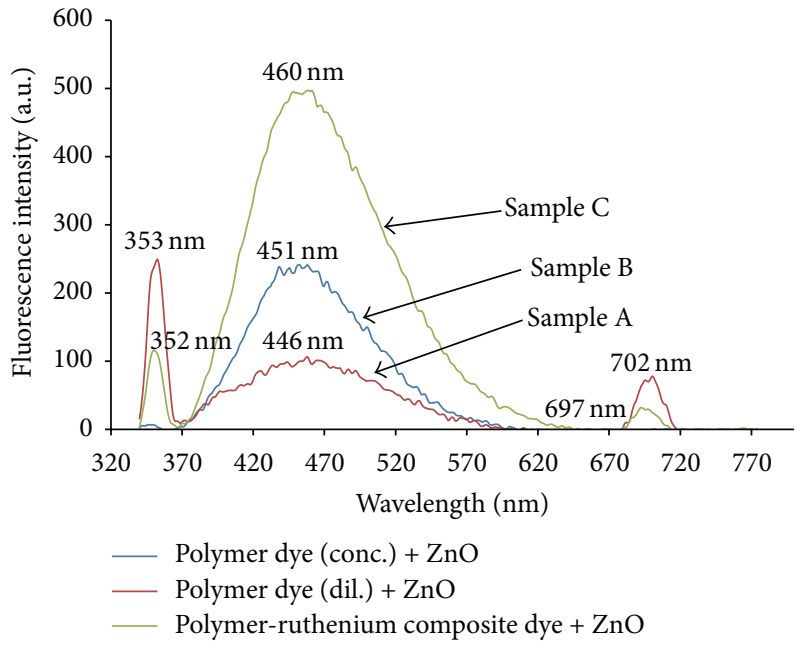

Figure 7: Fluorescence spectra of different samples: (A) polymer dye $\mathbf{A}$ (dil.) + $\mathrm{ZnO}$, (B) polymer dye $\mathbf{A}$ (conc.) $+\mathrm{ZnO}$, and (C) polymer-ruthenium composite dye $\mathbf{B}+\mathrm{ZnO}$.

improvement in the photon-to-electric power conversion efficiency was due to the good dye absorption stage and induced charge carrier injection of electrons from LUMO of polymer dye material to conduction band of ruthenium metal complex molecules. Polymer dye and ruthenium metal complex based hybrid nanostructure can also be useful in various photoluminescent applications other than DSSCs.

3.6. IPCE Spectra of Hybrid $\mathrm{ZnO}$ Based DSSCs. The incident photon-to-current conversion efficiency (IPCE) spectra for polymer dye capped $\mathrm{ZnO}$ based DSSCs were measured as shown in Figure 11. IPCE is defined as the total number of collected charge carriers (electrons) per incident photon. IPCE is evaluated by measuring the short circuit current density $\left(J_{\text {sc }}\right)$ at different wavelengths $(\lambda)$ within the spectrum using [38]

$$
\operatorname{IPCE}(\%)=1240\left(\frac{J_{\mathrm{sc}}}{\lambda \cdot P_{\mathrm{in}}}\right)
$$

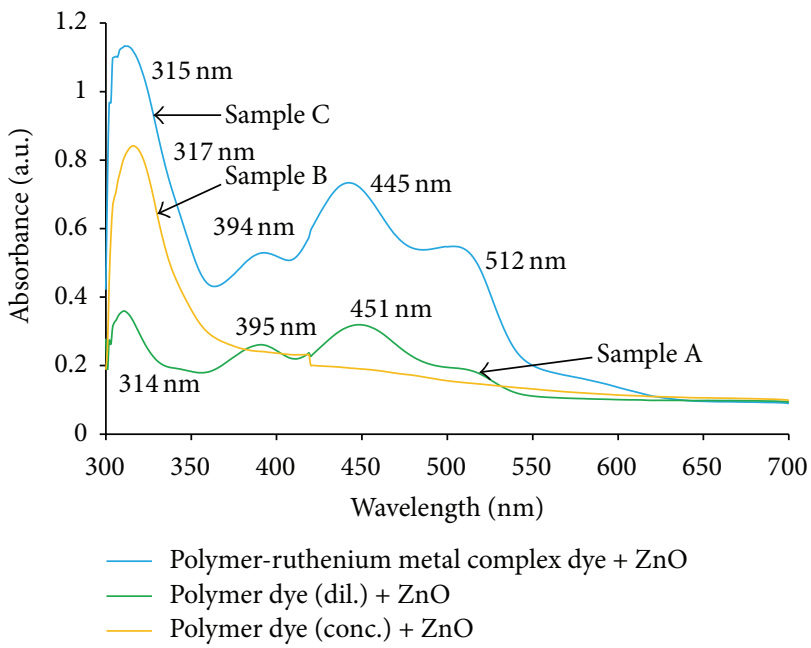

Figure 8: UV-visible spectra of different samples: (A) polymer dye $\mathbf{A}$ (dil.) $+\mathrm{ZnO}$, (B) polymer dye $\mathbf{A}$ (conc.) + $\mathrm{ZnO}$, and (C) polymerruthenium composite dye $\mathbf{B}+\mathrm{ZnO}$.

where $\lambda$ is the wavelength, $J_{\text {sc }}$ is short circuit current density $\left(\mathrm{mA} / \mathrm{cm}^{2}\right)$, and $P_{\text {in }}$ is the incident radiative power $\left(\mathrm{mW} / \mathrm{cm}^{2}\right)$. Figure 11 shows the comparison of IPCE spectra for $\mathrm{ZnO}$ based DSSCs fabricated from polymer dye $\mathbf{A}$ (dil.), polymer dye $\mathbf{A}$ (conc.), and polymer-ruthenium composite dye $\mathbf{B}$, respectively. The IPCE spectra of polymer-ruthenium composite dye B display a broader band between $300 \mathrm{~nm}$ and $750 \mathrm{~nm}$ compared to polymer dye $\mathbf{A}$ (dil.) and polymer dye $\mathbf{A}$ (conc.). The trend of significant enhancement of IPCE spectra follows the good short circuit current density $\left(J_{\mathrm{sc}}\right)$ and optimal efficiency $(\eta)$ of the solar cell.

\section{Conclusion}

In this research work, we have synthesized, characterized, and evaluated the optoelectronic and photovoltaic performances of polymer decorated organic-inorganic hybrid $\mathrm{ZnO}$ based dye-sensitized solar cells. For evaluating the performances of 


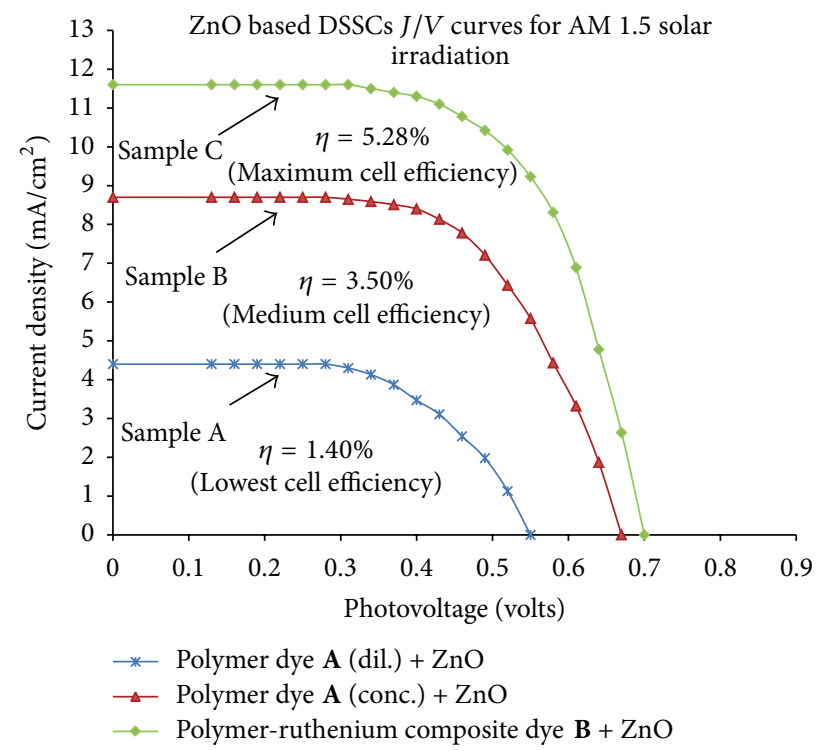

FIGURE 9: Current density and photovoltage response curves for different $\mathrm{ZnO}$ based DSSCs: (A) polymer dye $\mathbf{A}$ (dil.) + $\mathrm{ZnO}$, (B) polymer dye $\mathbf{A}$ (conc.) + $\mathrm{ZnO}$, and $(\mathrm{C})$ polymer-ruthenium composite dye $\mathbf{B}+\mathrm{ZnO}$ based DSSC.

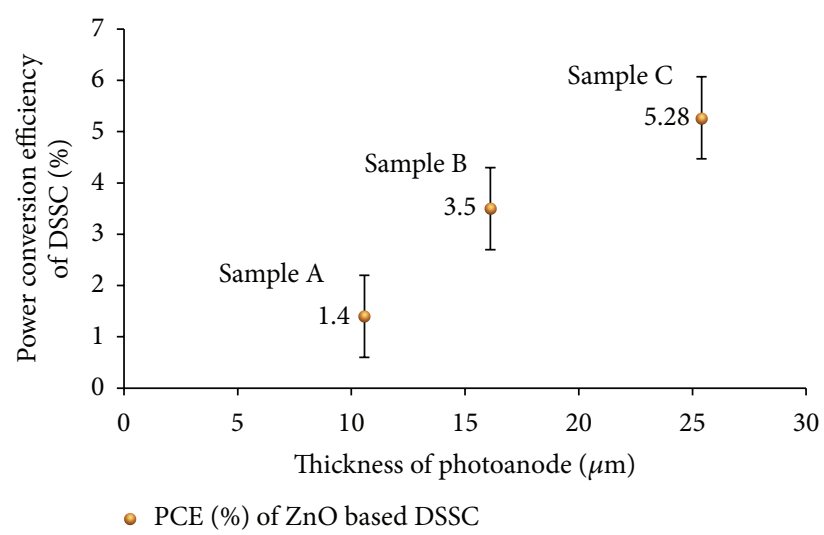

FIgURE 10: Comparison of thickness of photoanode and power conversion efficiency $(\eta)$ of samples (A) polymer dye A (dil.), (B) polymer dye $\mathbf{A}$ (conc.), and (C) polymer-ruthenium composite dye B decorated $\mathrm{ZnO}$ based DSSCs.

the first two samples of ZnO DSSCs, we have used a capping agent 2-thiophenecarboxaldehyde (2-TPC). In the third case, polymer-ruthenium metal complex based composite dye had been prepared and was used as a good dying agent in the fabrication of $\mathrm{ZnO}$ DSSC. Polymer dye $\mathbf{A}$ and polymerruthenium metal complex based composite dye $\mathbf{B}$ decorated ZnO DSSCs had shown significant optical and photophysical properties. The polymer-ruthenium composite dye $\mathbf{B}$ based ZnO DSSC had attained the highest power conversion efficiency of $5.28 \%$, which was enhanced by $1.78 \%$ and $3.88 \%$ compared to polymer dye A (concentrated) and polymer dye A (diluted) based ZnO DSSCs, respectively. Ruthenium metal

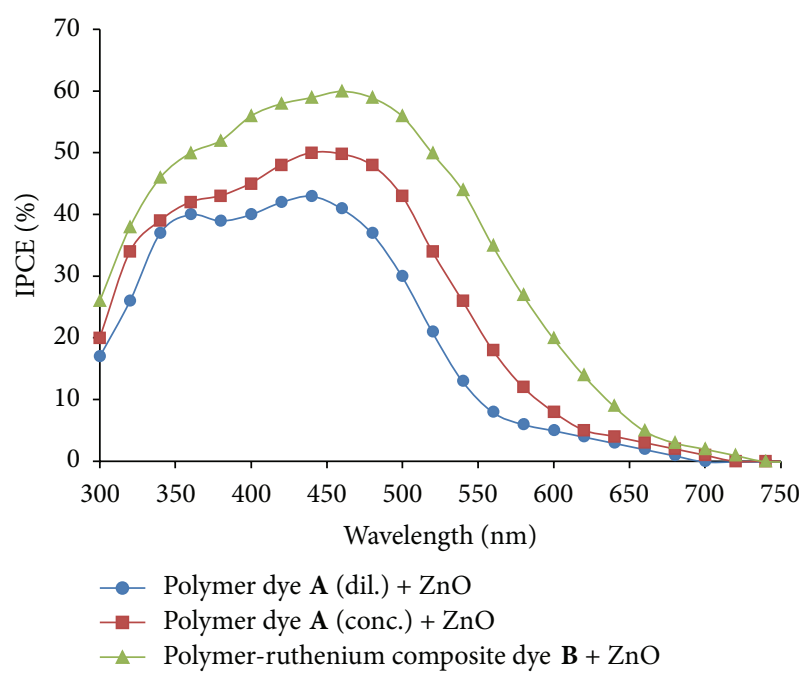

FIgure 11: IPCE spectra of $\mathrm{ZnO}$ based DSSCs for polymer dye $\mathbf{A}$ (dil.), polymer dye A (conc.), and polymer-ruthenium composite dye $\mathbf{B}$.

complex acted as a good sensitizer for increasing the light harvesting capacity of $\mathrm{ZnO}$ solar cell. Hence, the nature of hybrid organic/inorganic ZnO based DSSC performed efficiently for converting solar radiations into electricity and can be implemented commercially for potential optoelectronic and photovoltaic applications.

\section{Competing Interests}

The authors declare no competing financial interests.

\section{Acknowledgments}

The authors are very grateful to laboratory facilities for synthesis and measurement purposes at Punjab University, Chandigarh, and Indian Institute of Technology, Ropar, Punjab (India). The authors are also grateful to I. K. Gujral Punjab Technical University, Jalandhar, Kapurthala, for providing necessary research facilities.

\section{References}

[1] M. Wright and A. Uddin, "Organic-inorganic hybrid solar cells: a comparative review," Solar Energy Materials \& Solar Cells, vol. 107, pp. 87-111, 2012.

[2] R. Liu, "Hybrid organic/inorganic nanocomposites for photovoltaic cells," Materials, vol. 7, no. 4, pp. 2747-2771, 2014.

[3] P. Ruankham, S. Yoshikawa, and T. Sagawa, "Improved performance of hybrid $\mathrm{ZnO}$ /polymer solar cell via construction of hierarchical nanostructures and surface modification of $\mathrm{ZnO}$," Japanese Journal of Applied Physics, vol. 53, no. 1, Article ID 01AB14, 2014.

[4] I. Gonzalez-Valls and M. Lira-Cantu, "Effect of testing conditions on the photovoltaic performance of $\mathrm{ZnO}$-based dye sensitized solar cells," Physics Procedia, vol. 8, pp. 28-32, 2010.

[5] G. Rey, N. Karst, V. Consonni et al., "Zinc oxide nanostructured material for dye sensitized solar cells," in Proceedings of the 35th 
IEEE Photovoltaic Specialists Conference (PVSC '10), pp. 32603263, June 2010.

[6] J. Singh, J. Im, J. E. Whitten, J. W. Soares, and D. M. Steeves, "Chemisorption of a thiol-functionalized ruthenium dye on zinc oxide nanoparticles: implications for dye-sensitized solar cells," Chemical Physics Letters, vol. 497, no. 4-6, pp. 196-199, 2010.

[7] C.-H. Ku and J.-J. Wu, "Electron transport properties in $\mathrm{ZnO}$ nanowire array/nanoparticle composite dye-sensitized solar cells," Applied Physics Letters, vol. 91, no. 9, Article ID 093117, 2007.

[8] V. Dutta, "Energy," Procedia, vol. 3, p. 58, 2011.

[9] Y. Tian, C. Hu, Q. Wu, X. Wu, X. Li, and M. Hashim, "Investigation of the fill factor of dye-sensitized solar cell based on $\mathrm{ZnO}$ nanowire arrays," Applied Surface Science, vol. 258, no. 1, pp. 321-326, 2011.

[10] Q. Zhang, K. Park, and G. Cao, "Synthesis of ZnO aggregates and their application in dye-sensitized solar cells," Material Matters, vol. 5, pp. 32-39, 2010.

[11] K. Premaratne, G. R. A. Kumara, R. M. G. Rajapakse, and M. L. Karunarathne, "Highly efficient, optically semi-transparent, $\mathrm{ZnO}$-based dye-sensitized solar cells with Indoline D-358 as the dye," Journal of Photochemistry and Photobiology A: Chemistry, vol. 229, no. 1, pp. 29-32, 2012.

[12] J. A. Anta, E. Guillen, and R. Tena-Zaera, "ZnO-based dyesensitized solar cells," Journal of Physical Chemistry, vol. 116, no. 21, pp. 11413-11425, 2012.

[13] T. Takagahara and K. Takeda, "Theory of the quantum confinement effect on excitons in quantum dots of indirect-gap materials," Physical Review B, vol. 46, no. 23, pp. 15578-15581, 1992.

[14] I. B. Karki, J. J. Nakarmi, P. K. Mandal, and S. Chatterjee, "Effect of organic dyes on the performance of $\mathrm{ZnO}$ based dyesensitized solar cells," Applied Solar Energy, vol. 49, no. 1, pp. 40-45, 2013.

[15] A. Guchhait, A. K. Rath, and A. J. Pal, “To make polymer: quantum dot hybrid solar cells NIR-active by increasing diameter of PbSnanoparticles," Solar Energy Materials and Solar Cells, vol. 95, no. 2, pp. 651-656, 2011.

[16] H. M. Upadhyaya, S. Senthilarasu, M.-H. Hsu, and D. K. Kumar, "Recent progress and the status of dye-sensitised solar cell (DSSC) technology with state-of-the-art conversion efficiencies," Solar Energy Materials and Solar Cells, vol. 119, pp. 291-295, 2013.

[17] N. Memarian, I. Concina, A. Braga, S. M. Rozati, A. Vomiero, and G. Sberveglieri, "Hierarchically assembled $\mathrm{ZnO}$ nanocrystallites for high-efficiency dye-sensitized solar cells," Angewandte Chemie-International Edition, vol. 50, no. 51, pp. 1232112325, 2011.

[18] Q. Zhang, T. P. Chou, B. Russo, S. A. Jenekhe, and G. Cao, "Aggregation of $\mathrm{ZnO}$ nanocrystallites for high conversion efficiency in dye-sensitized solar cells," Angewandte ChemieInternational Edition, vol. 47, no. 13, pp. 2402-2406, 2008.

[19] B. Onwona-Agyeman, M. Nakao, and T. Kitaoka, "Photovoltaic performance of spray-coated zinc oxide nanoparticles sensitized with metal-free indoline dyes," Journal of Materials Science Research, vol. 3, no. 1, pp. 87-93, 2014.

[20] Y.-H. Kim, I.-K. Lee, Y.-S. Song et al., "Influence of $\mathrm{TiO}_{2}$ coating thickness on energy conversion efficiency of dye-sensitized solar cells," Electronic Materials Letters, vol. 10, no. 2, pp. 445449, 2014.
[21] Y. Noh and O. Song, "Formation of ruthenium-dots on counter electrodes for dye sensitized solar cells," Electronic Materials Letters, vol. 10, no. 1, pp. 263-266, 2014.

[22] S. Ameen, M. S. Akhtar, M. Song, and H. S. Shin, "Metal oxide nanomaterials, conducting polymers and their nanocomposites for solar energy," in Solar Cells-Research and Application Perspectives, chapter 8, InTech, Rijeka, Croatia, 2013.

[23] P. Suri and R. M. Mehra, "Effect of electrolytes on the photovoltaic performance of a hybrid dye sensitized $\mathrm{ZnO}$ solar cell," Solar Energy Materials \& Solar Cells, vol. 91, no. 6, pp. 518-524, 2007.

[24] S. Wu, Q. Tai, and F. Yan, "Hybrid photovoltaic devices based on poly (3-hexylthiophene) and ordered electrospun $\mathrm{ZnO}$ nanofibers," Journal of Physical Chemistry C, vol. 114, no. 13, pp. 61976200, 2010.

[25] F. Tong, K. Kim, D. Martinez et al., "Flexible organic/inorganic hybrid solar cells based on conjugated polymer and $\mathrm{ZnO}$ nanorod array," Semiconductor Science and Technology, vol. 27, no. 10, Article ID 105005, 2012.

[26] S. A. Kislenko, R. K. Amirov, O. S. Popel', and I. S. Samoilov, "Dye-sensitized solar cells: present state and prospects for future development," Thermal Engineering, vol. 57, no. 11, pp. 969-975, 2010.

[27] T. Ganesh, H.-M. Nguyen, R. S. Mane et al., "Promising ZnObased DSSC performance using HMP molecular dyes of high extinction coefficients," Dalton Transactions, vol. 43, no. 29, pp. 11305-11308, 2014.

[28] V. Kumar, N. Singh, V. Kumar et al., "Doped zinc oxide window layers for dye sensitized solar cells," Journal of Applied Physics, vol. 114, no. 13, Article ID 134506, 2013.

[29] M. Gratzel, "Dye-sensitized solar cells," Journal of Photochemistry and Photobiology C: Photochemistry Reviews, vol. 4, no. 2, pp. 145-153, 2003.

[30] M. Taguchi, A. Yano, S. Tohoda et al., "24.7\% Record efficiency HIT solar cell on thin silicon wafer," IEEE Journal of Photovoltaics, vol. 4, no. 1, pp. 96-99, 2014.

[31] A. L. Patterson, "The scherrer formula for X-ray particle size determination," Physical Review, vol. 56, no. 10, pp. 978-982, 1939.

[32] J. G. Lu, Z. Z. Ye, J. Y. Huang et al., "ZnO quantum dots synthesized by a vapor phase transport process," Applied Physics Letters, vol. 88, no. 6, Article ID 063110, 2006.

[33] W. J. E. Beek, M. M. Wienk, and R. A. J. Janssen, "Efficient hybrid solar cells from zinc oxide nanoparticles and a conjugated polymer," Advanced Materials, vol. 16, no. 12, pp. 10091013, 2004.

[34] U. Manzoor, M. Islam, L. Tabassam, and S. U. Rahman, "Quantum confinement effect in $\mathrm{ZnO}$ nanoparticles synthesized by co-precipitate method," Physica E: Low-Dimensional Systems and Nanostructures, vol. 41, no. 9, pp. 1669-1672, 2009.

[35] M. Al-Eid, S. H. Lim, K.-W. Park et al., "Facile synthesis of metal-free organic dyes featuring a thienylethynyl spacer for dye sensitized solar cells," Dyes and Pigments, vol. 104, pp. 197-203, 2014.

[36] W.-C. Chang, C.-H. Lee, W.-C. Yu, and C.-M. Lin, "Optimization of dye adsorption time and film thickness for efficient $\mathrm{ZnO}$ dye-sensitized solar cells with high at-rest stability," Nanoscale Research Letters, vol. 7, no. 1, article 688, 10 pages, 2012.

[37] N. Sakai, T. Miyasaka, and T. N. Murakami, "Efficiency enhancement of $\mathrm{ZnO}$-based dye-sensitized solar cells by lowtemperature TiCl4 treatment and dye optimization," Journal of Physical Chemistry C, vol. 117, no. 21, pp. 10949-10956, 2013. 
[38] W.-C. Chang, L.-Y. Lin, and W.-C. Yu, "Dual-functional zinc oxide aggregates with reaction time-dependent morphology as the dye-adsorption layer for dye-sensitized solar cells," Journal of Electroanalytical Chemistry, vol. 757, article 2291, pp. 159-166, 2015. 

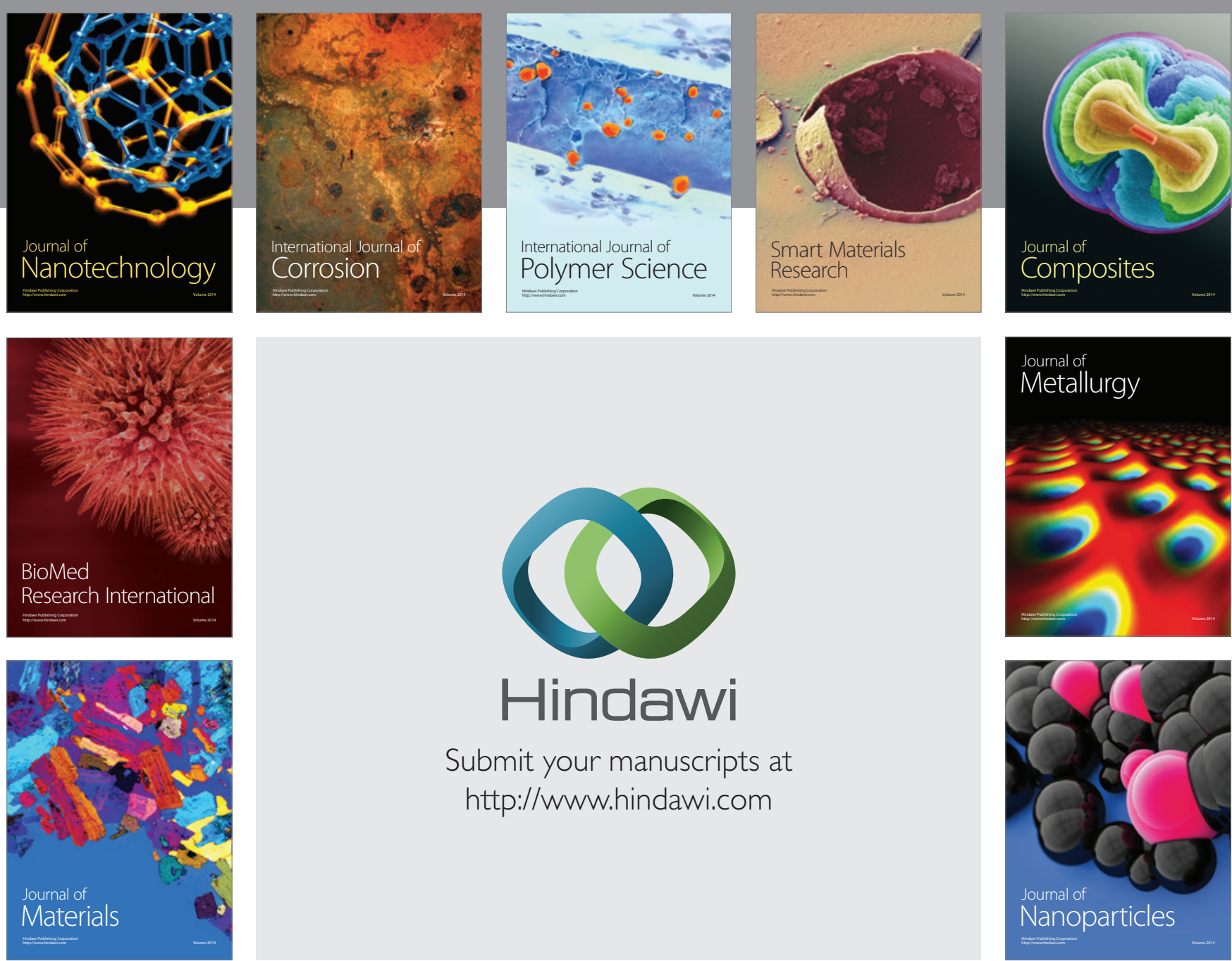

\section{Hindawi}

Submit your manuscripts at

http://www.hindawi.com

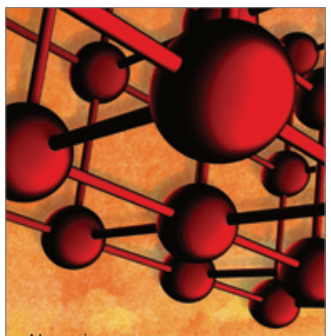

Materials Science and Engineering
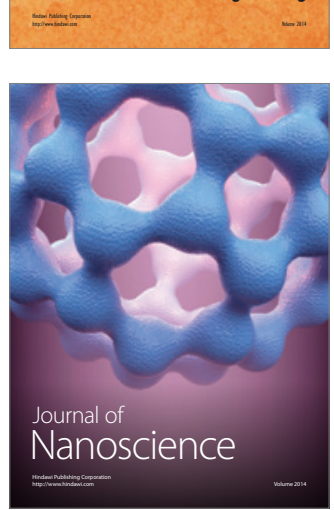
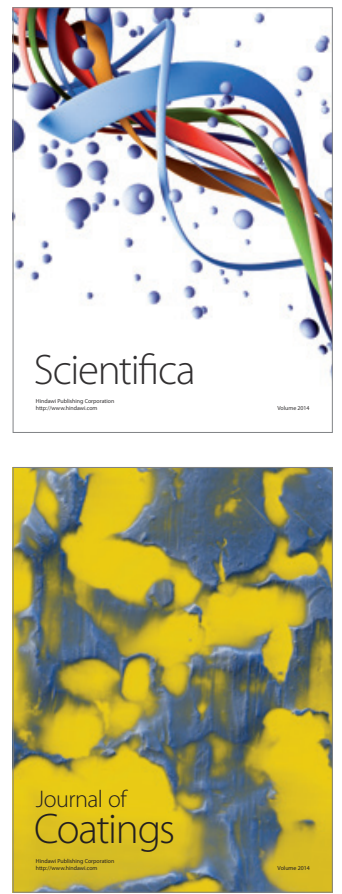
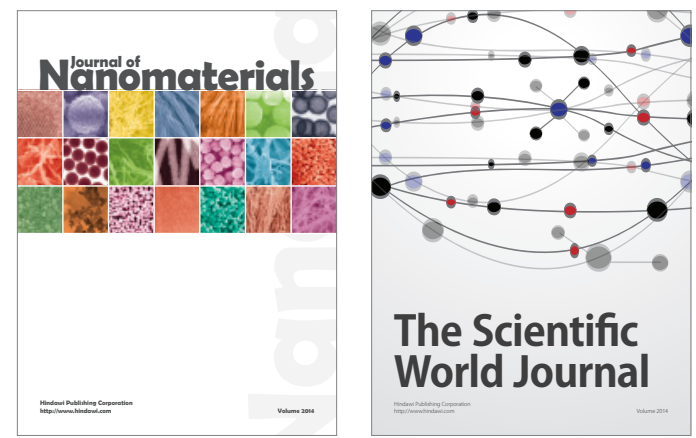

The Scientific World Journal
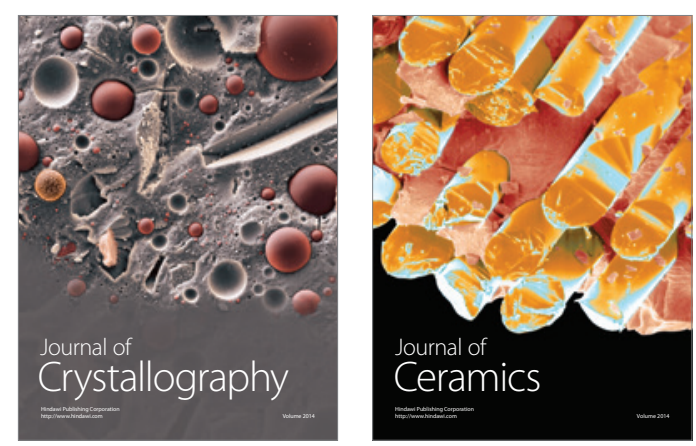
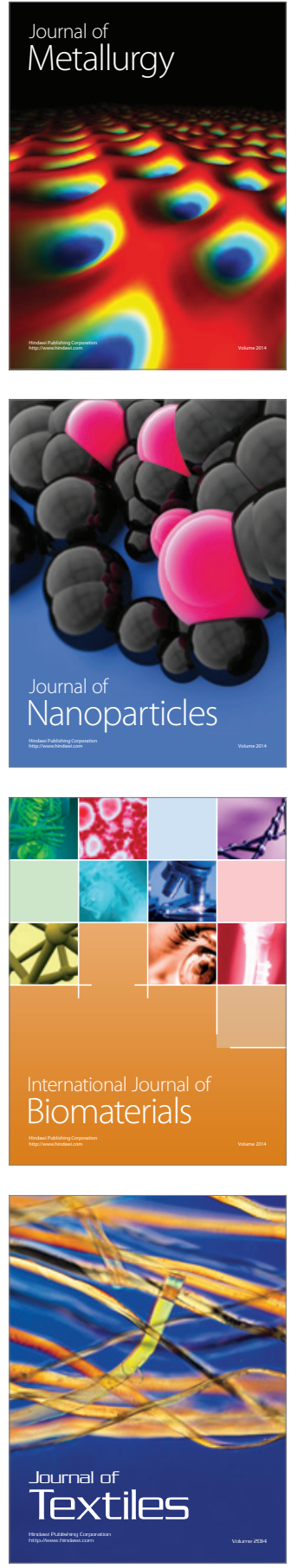